\title{
BERNARD SHAW'S VICHIAN-HEGELIAN HERO IN HEARTBREAK HOUSE (1919)
}

\author{
Atalay GÜNDÜZ1
}

\begin{abstract}
This study aims to read one of Shaw's most significant plays Heartbreak House (1919) from a Vichian-Hegelian perspective. Just like Vico and Hegel who believe that heroes play a major role in the formation of human history, Shaw introduces Hector with all the potential and capabilities of a hero who would be expected to play a formative role in one of the most dramatic phases of human history. Shaw's Great War play dramatizes his generation's heartbreak, the moral and political paralysis of the educated and cultured classes of Europe. The ship-house in the play is the allegorical representation of all Europe drifting to the rocks while the passengers and the captain are consumed in their domestic, petty, egotistical whims and passions wasting their good energies on trivialities but no one intervening. It has an unmistakable Homeric tune to it as many scholars have drawn our attention. Hector is one of the most central characters of the play and that he stands for one of the most fundamental themes in the play: the potential hero, leader decapacitated by his weakness for women, particularly by his wife Hesione Hushabye. Shaw constructs the educated liberal classes, heartbreakers in opposition to "barbarian" horseback dwellers.
\end{abstract}

Keywords:.Heartbreak House, Bernard Shaw, Vico, Hegel, hero, morals

Gündüz, Atalay. "Bernard Shaw's Vichian-Hegelian Hero in Heartbreak House (1919)”. idil 6.31 (2017): 873-889.

Gündüz, A. (2017). "Bernard Shaw's Vichian-Hegelian Hero in Heartbreak House (1919)". idil 6 (31), s.873-889.

\footnotetext{
${ }^{1}$ Doç. Dr., Dokuz Eylül Üniversitesi, Edebiyat Fakültesi, Mütercim-Tercümanlık Bölümü, atalaygunduz(at)hotmail.com
} 


\title{
KIRGINLAR EVI'NDE (1919) SHAW'UN VICOCU- HEGELCI KAHRAMANI
}

\begin{abstract}
$\ddot{O z Z}$
$\mathrm{Bu}$ çalışma Shaw'un en önemli oyunlarından biri olan Kırgınlar Evi'ni (1919) Vicocu-Hegelci bir perspektiften incelemektetir. Vico ve Hegel gibi Shaw da "kahramanların" insanlık tarihinde önemli bir dönüştürücü rolüne sahip olduğuna inanmaktadır. İşte bu inançla, Shaw Hector adındaki karakterini tesadüf olmanın çok ötesinde insanlık tarihinin en şekillendirici tarihsel dönemeçlerinden birinde bir kahramanın sahip olması gereken her türlü beceri ve güçle donatmıştır. Shaw’un birinci Dünya Savaşı sürerken yazdığı Kırgınlar Evi, kuşağının ve çağının büyük umutlar beslenen eğitimli ve kültürlü sınıflarının ahlaki ve siyasi felcinden duyduğu kalpkırıklığını oyunlaştırıyor. Oyundaki gemi-ev alegorik olarak bir gemiye benzetilen Avrupa'nın kayalıklara doğru sürüklenirken kaptanın ve mürettebatın nasıl kendi basit, bencil, küçük kaprisleri ve tutkularıyla iyi enerjilerini boşa harcadıkları ama esas müdahale edilmesi gereken konuda elleri kolları bağlı oturduklarını anlatıyor. Bir çok eleştirmenin belirttiği gibi inkar edilemez Homer etkileri taşıyan oyunda kadınlara düşkünlüğünden, özellikle karısı Hesione'ye, dolayı kapasitesini kullanamayan Hektor en merkezdeki karakterlerden biri. Shaw oyununu özellikle eğitimli liberal kalp kıranlara karşı "barbar" at sırtında oturanlar ikili karşıtlığı üzerine oturtuyor.
\end{abstract}

Anahtar kelimeler: Kırgınlar Evi, Bernard Shaw, Vico, Hegel, kahraman, ahlak 


\section{Introduction}

Shaw started to write Heartbreak House in 1916 and revised it in most part of the 1917 (Holroyd, 1991: 21). Even long before he started to write the play he had the idea of writing a play in the Chekhovian manner. In the preface to the play Shaw expresses his boundless admiration for Chekhov especially but also for Tolstoy and Gorki. In that the play has the subtitle: "A Fantasia in the Russian Manner on English Themes". As Ibsen basically focuses on Middle Classes, Chekhov chooses country houses as his setting and depicts the heartbroken people of the new age. In the "Preface" Shaw declares that "Heartbreak House is cultured, leisured Europe before the war" (Shaw, 1919: 7). Kruse also observes that Heartbreak House in a sense should be thought as a third response to the Great War by Shaw. The first being The Common Sense About the War (1914), the second "Preface" to the said play and the third the play itself. $^{2}$ (Kruse, 1987: 100-119)

Many critics observe that though Heartbreak House follows certain patterns that we come across in Getting Married (1908) and Misalliance (1910), it still has a unique place in the Shavian canon. Although Shaw liked to explain and defend his plays through prefaces, letters to the press and fictional interviews; Heartbreak House was one of the few plays that Shaw rejected to talk about. Contrary to his working habits, Shaw stated that Heartbreak House "Began with an atmosphere and does not contain a word that foreseen before it was written". When he was asked by his actors what this rather enigmatic and confusing play meant, he replied: "How should I know? I am only the author." A reply quite untpypical of Shaw as he would not let anyone else the authority to know his plays better than he did. (Ervine, 1990: 296)

Heartbreak House is a favorite among drama critics and Shaw scholars. ${ }^{3}$ (Young,1953: 232; Gibbs, 1983: 177; Grene, 1984: 114) Grene accounts for the popularity of the play among critics thus "Formally, it represents something of a new departure for Shaw, with a technique and structure which can be compared with more modern dramatists." Thus the play offers readings in a quite wide spectrum with "its use of symbolism, its allusiveness, its free adaptation of the Chekhovian style, relate it to the modernist mode" (Grene, 1984: 114). Scholarship on the play basically focused on the formal aspects (of the play Garner, 1989; Hornby, 1968-1969; Hoy, 1971); investigating Shaw's debt to Chekhov, Dickens and Tolstoy (Freeborn, 1999-2000;

\footnotetext{
${ }^{2}$ I distinguish the preface from the play since Shaw does not see his prefaces as a prelude to his plays that would directly explain the plays but as parallel texts, in which he would discuss themes or issues that he could not discuss in the play. In that the prefaces are usually taken as independent bodies of texts in Shaw studies. "It is nearly always misleading to read a Shaw preface as an introduction to the play it prefaces, but never so more than with Heartbreak House" (Grene 11).

${ }^{3}$ In a 2012 panel held in New York for the production of Man and Superman by the Irish Repertory theatre, eminent Shaw scholars and actors, six out of nine, replied that Heartrbreak House was their favorite.
} 
Frank, 1977; Handley, 1999), or Shaw's expressionist technique in the play, the play's peculiar connection with the modernist writers like Beckett, Joyce and Albee: a response to the war which deepened and darkened Shaw's drama into a tragic vision (Coleman, 1966-1967). In Shaw's earlier plays war is used as an element to attack the popular romantic conventions of Victorian age. As Griffith puts it war is "little more than a harmless diversion from the affairs of the world." (Griffith, 1993: 217)

\section{Shaw's, Vico's and Hegel's Moral Heroes}

Before delving deeper into the Vichian and Hegelian hero, let us have a look at how Merriam-Webster defines "hero":

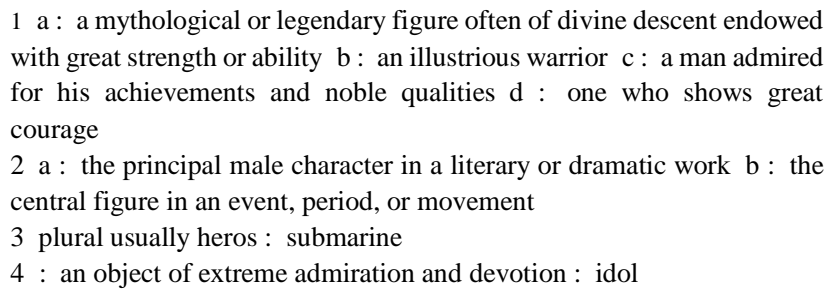

With the choice of Hector as a name for the character Shaw covers the entries a whole spectrum of the dictionary entries except number 3. In fact, in his "The Author's Apology" to Mrs Warren's Profession (1902) Shaw states that stage heroes like Paris or Antony "who sacrifice every other consideration to love" are actually like "lunatics or dipsomaniacs"; on the other hand, "Hector is the world's hero" (Shaw, 1902: 31425). What makes Hector the world's hero is crystallized in his reply to Helen when she asks him to sit a rest a little with her: "My heart races to help our Trojans - they long for me, sorely, whenever I am gone." Homer's Hector's heart beats for the Trojans, the answer of a person whose existence has mingled into the universal good, a real hero in Vicchian and Hegelian terms.

Vico who divided the human history into three distinct ages calling them age of gods, age of heroes and age of man, contend that "founders of gentile humanity" by trying to grasp certain aspects of their surroundings and trying to interpret their own experience laid the foundations for many different fields of study. According Auerbach the shift from the age of god to the age of hero is "political and economic" one. The change came with ancient human societies starting establishing settlements and transforming nomadic societies into settled ones. (Auerbach, 1949: 192.) The first settlers having gained material superiority over the nomadic majority looked like heroes 
to the unsettled nomads and used this superiority to enslave them and organize the extraction of their labor for the benefit of the few. Auerbach relates the tension between the labor slaves and "fathers" with these words:

\begin{abstract}
Stationary life and family constitution had given to the minority of settlers a superiority of wealth, material power, and religious prestige over the remnant of nomads, who finally were obliged to have recourse to the families of the fathers for protection and better living conditions; they were accepted as labor-slaves, as dependent members of the family of the first fathers or "heroes"; they were not admitted to the ritual ceremonies, and consequently had no human rights, no legal matrimony, no legitimate children, no property. But after a certain time the slaves or famuli began to rebel; a revolutionary movement developed, religious as well as social, for participation in the ceremonies, in legal rights and property. This movement obliged the isolated fathers to unite for defense, and to constitute the first communities, the heroic republics. (Auerbach, 1949: 192)
\end{abstract}

Having thus referred to the political and economic connotations of the hero from a Vichian perspective as presented by one of the most eminent students of Vico, I would like to point out a point which is more relevant to the point I am making in this study. The metaphysically and theologically disposed moral aspect of the hero for the gentile people: "by means of their natural theology (or metaphysics) imagined the gods; how by means of their logic they invented languages; by morals, created heroes." (Vico, 1725: 86-87) Vico makes his point further stating that the ancient Greek scholars who followed just after the philosophers bestowed the title of "hero" only to those who brought a significant benefit to the whole nation. Although the heroes could give the impression that all their feats were performed "only through an excess of individual feeling for their own sovereignty, which was preserved for them by their fatherland through their families." Vico emphasizes the point that in the end "with the word res ['concern'] understood, the fatherland was called the 'the concern of the fathers'. From such a state of affairs, Vico attempts to explain the brith of "republic": "respublica ["the public concern'], which is almost respopulica, or the concern of all the people'. (Vico, 1725: 86-87) Thus, the scholar's hero is a public spirited moral person signifying the virtues of the society as projected the wise. $\mathrm{Hegel}^{4}$ who is closely associated with Vico

\footnotetext{
${ }^{4}$ Although Shaw does not refer to Hegel very often, apart from a few references in his letters edited by Laurence, we can still assume that there must be an indirect influence towards Marx. On the Hegelian link, Shaw's biographer Holroyd observes how Hegelian method of thinking shaped his style as a dramatist: "..of reconciling opposites and bringing harmony to his life. Through an act of will and sustained act of faith he wished to create the new drama in which, as in a series of parables, he could rewrite history and set it on a new course." Holroyd furthermore extends his observations describing how that Hegelian approach was translated into Shaw's political perspective providing Shaw with a critical point in his view of Marx: "The Hegelian structure became a model for his thought, working in terms of dramatic dialogue and as a metaphor for conception and birth. Reviewing a novel Moncure Conway early in 1888, he had written of Hegelianism having entered German socialism, adding that 'its positive side has never been adapted and translated into practical English
} 
also makes a similar point on the "concern for all the people", calling this with a more abstract term "universal". Perceiving the state as the legitimate embodiment of this alturistic public spiritedness Hegel argues that:

...the universal becomes united with existence in general, just as the [merely] existent consciousness through this renunciation develops into an essential existence. That from which this consciousness alienates itself in serving the universal is the consciousness that is immersed in [mere] existence; but the being that is alienated from itself is the initself. Through this development, therefore, it wins self-respect and the respect of others.

(Hegel, 1807: 306)

This self-forgetting in Hegelian terms, mixing into the universal gives one the recognition of the others but most importantly the "self-respect" or the self recognizing itself as an entity worthy of its place in this World, deserving its existence as a harmonious and beneficial part of the whole. One of my most favorite Shaw statements makes a similar point:

This is the true joy in life, the being used for a purpose recognized by yourself as a mighty one; the being thoroughly worn out before you are thrown on the scrap heap; the being a force of nature instead of a feverish selfish little clod of ailments and grievances complaining that the World will not devote itself to making you happy. (Shaw, 1903: 32)

Thus prescribing the happiness one might aspire to get, Shaw also describes what he deems to be the "real" tragedy in life "being used by personally minded men for purposes which you recognize to be base". (Shaw, 1903: 32) In a most Hegelian sense, while self-respect is the means of "happiness" for anyone, the opposite, the loss of it is the sole source of "tragedy" as Shaw calls it. Glorifying the Romans with a nationalist prejudice, as he probably presumes himself to be the inheritor of the Roman Empire Vico observes that heroes of the classical times had the following virtues:

But there was no deceit in the first founders of the cities of Latium or any of the other cities in the world. There was [only] their nature, and that the magnanimous nature of heroes who were incapable of lying, which is a base and cowardly artifice, for they truly understood themselves to be the children of the buried, from whose ranks their women still came. Thus, in addition to the first feature of heroism, which was to annihilate the thieves, here lay the second, which was to give succour to the endangered who sought their aid. Hence the Romans became the heroes of the world

politics, and it remained in the hands of Marx, chiefly effective as a scathing but quite negative criticism of industrial indivdualism." (Holroyd, 1989: 72) 
through these two arts: parcere subiectis et debellare superbos ['of sparing the conquered and subduing the proud']. (Vico, 1725: 91)

I would like to put emphasis on the first two virtues pointed by Vico: "incapable of lying" and "to annihilate the thieves" which I will discuss within the context of Heartbreak House further in the following parts. The last can also be related to Captain Shotover's past as a sea captain, and his reputation in Zanzibar as the one who has sold his soul to the devil. Shaw famously states his "passion for morals" in many different occasions. In one famous quotation in his Preface to Man and Superman Shaw declares that "for art's sake's alone I would not face the toil of writing a single sentence" (Shaw, 1903: 35).

Vico also adds that "from these first men, stupid, insensate, and horrible beasts philosophers and philologians should have begun their investigations of the wisdom of the ancient gentiles." In that to contextualize Hector in its Homeric tradition and seek the morals proposed by Homer in Iliad is a good staring point for the inquiry. In Iliad Hector is the leader and the foremost commander of the Trojan Army which defend their homeland against and invading army. He represents the hope of the Trojan people, and unlike his brother Paris who with his laxity and loose morals brought the calamity to the Trojan people Hector stands as a bulwark of power and morality in the city. He is respected and obeyed by all the Trojans, including the king his father Priam. Ironically, his corpse suffers the most "atrocious" disrespect and is humiliated by Achilleus for revenge; for Patroclus. The circumstances are similar in both a major war threatens the survival of both nations and in Hector Hushabye's case even the survival of the humanity as the mass destructive power of the weapons are even more lethal in the twentieth century.

Shaw has his moral heroes in his plays even from the very beginning of his first play Widowers' Houses (1892). Yet these heroes are far from representing the conventional morality of their times: Charteris in The Philanderer (1893), Jack in Man and Superman (1903) for instance in contrast to middle class morality which condemns babies out of wedlock celebrates Violet's news that she would have a baby. In Devil's Disciple (1897) Richard Dudgeon also disrupts the moral grounds of the puritan community in New Hampshire, in John Bull's Other Island (1904) Father Keegan preaches a totally different morality inviting the audience to see the whole nature and animals as their brethren. In Pygmalion (1913) Eliza's father Mr Doolittle is another sample to these heroes and moral issues in Shaw's plays. On the other hand, Shaw has

\footnotetext{
${ }^{5}$ In his Sartor resartus; and, On heroes, hero-worship and the heroic in history (1836) Thomas Carlyle makes a similar point stating that "I should say sincerity, a deep, great, genuine sincerity, is the first characteristic of all men in any way heroic." (Carlyle, 1836: 300)
} 
a quite different approach in Heartbreak House. Hector ${ }^{6}$ as the name with its Homeric allusion is the most readily available character to the characters listed above. What makes Hector heroic in Iliad is his total devotion to the salvation of his people and the city. Li, among many other critics, draws a direct parallel between Shaw's Heartbreak House and Homer's Iliad establishing connections between Shaw's characters and Homer's. (Li, 1998: 83) Weintraub argues that the way Shaw draws from Greek myths is quite problematic, as Shaw tries to evade one to one parallels with the mythical figures. Yet again, Weintraub's reading of Shaw's Hector is worth quoting here:

\begin{abstract}
Hector Hushabye is the play's soothsayer, the prophet of war and chaos and the possible doom of their society, a role that the Troy myth gives to Cassandra. Risk-seeking and flirtatious, Hector conceals his twentiethcentury sword in a gentleman's walking stick, a fantasy weapon rather than a warrior's sheath. More than a hint is symbolized here of the smug and complacent Troy, with blundered into a lost war over a case of aristocratic adultery. (Weintraub, 2009: 43)
\end{abstract}

Drawing this direct parallel, Weintraub's reading ends at that and does not go much further than that. He does not focus on Hector as a domesticated, diminished hero in Heartbreak House. Shaw's idea of a "hero" differs dramatically from the Victorian idea of a "chivalric hero". In Candida, Marchbank referring to medieval tradition says that "If I were a hero of old, I should have laid down my sword between us." (Shaw, 1898: 3991) To be a hero, heroic acts are the gestures of an old irrecoverable age. In Vichian terms these gestures belong to the age of the heroes. In the "Notes to Caesar and Ceopatra" epilogue to the play mentioned in the title, objecting to the conventional stage hero of the period Shaw contends that "Goodness, in its popular British sense of self-denial, implies that man is vicious by nature, and that supreme goodness is supreme martyrdom." (Shaw, 1901: 6550) According to Shaw this is an extremely superficial understanding of morals. Shaw prefers to allude to the lessons of a different era:

I follow the precedent of the ancient myths, which represent the hero as vanquishing his enemies, not in fair fight, but with enchanted sword, superequine horse and magical invulnerability, the possession of which,

\footnotetext{
${ }^{6}$ Does Shaw promote heroes in the conventional we way we know of them? It is really hard to say that in the sequel to Pygmalion where Shaw explicate why Eliza would not go for Higgins but for Freddy, Shaw says that "The weak may not be admired and hero-worshipped but they are by no means disliked or shunned; and they never seem to have the least difficulty in marrying people who are too good for them. They may fail in emergencies; but life is not one long emergency: it is mostly a string of situations for which no exceptional strength is needed, and with which even rather weak people can cope if they have a stronger partner to help them out. Accordingly, it is a truth everywhere in evidence that strong people, masculine or feminine, not only do not show any preference for them in selecting their friends." (Shaw, 1913: 26508) For Shaw once a person feels that $\mathrm{s} / \mathrm{he}$ is strong enough to protect and take care of partner's weakness, $\mathrm{s} / \mathrm{he}$ starts to look for other qualities in their partners. In Arms and the Man Shaw actually ridicules that hero-worshipping and reveals that it is a silly attitudinizing learned from melodramas. In many different occasions Raina expresses her melodramatic admiration for Sergius who was the "hero of the hour" for Raina. Yet Shaw again and again exposes how groundless these heroic postures were and in military terms they were mere suicidal stupidities. Sergius with his empty and vain gestures prove Shaw's point and admits his false courage.
} 
from the vulgar moralistic point of view, robs his exploits of any merit whatever. (Shaw, 1901: 6546-6551)

Shaw's approach to the issue is not to create any heroes in the conventional sense of the word. In his Don Juan ${ }^{7}$ play Man and Superman (1903) also, despite the title's suggestions of an expected hero at the end of the dream episode we are made to understand that "superman" is not a hero of exceptional and super powers or abilities but a better, a more virtuous, a more intelligent generation to be created. "ANA: Not yet created! Then my work is not yet done. (Crossing herself devoutly) I believe in the Life to Come. (Crying to the universe). A father! A father for the Superman!" (Shaw, 1903: 173) The dream section ends with these words and the play returns to the Sierra. In the epilogue to the same play entitled "The Revolutionist's Handbook" Shaw argues that

Until there is an England in which every man is a Napoleon, a Rome in
which every man is a Caesar, a Germany in which every man is a Luther
plus a Goethe, the World will be no more improved by its heroes than a
Brixton villa is improved by the pyramid of Cheops. The production of
such nations is the only real change possible to us. (Shaw, 1903: 224-225)

In that we can say that Shaw does not attribute superhuman strengths to his "hero" and believes that every person without exception carries the potential to be a hero given the opportunity and the right environment. Yet the culture, lifestyle, world view of the Heartbreak House society would not let Hector realize his capacity as a hero. Just as Priam was destroyed for the hedonism and irresponsible attitudes of Paris his younger son but at least protected nine years by the courage and strength of Hector. (Fagles, 1990: 113-114) Shaw's Hector Hushabye is miles away from Iliad's Hector's maturity and leadership, whiling away his time and energy and most importantly his intellectual capacity chasing young girls with an encouragement from his wife Ariadne. Li suggests that the first gesture we see Hector does on his intial appearance is to put his "hat and walking stick", his weapons on the table to take his stick to make a duel with an invisible enemy the moment he finds the stage all to himself. (Shaw, 1919: 83) On Hesione's effect on Hector, Captain Shotover remarks: "She has used you up and left you nothing" Shaw implies that the bohemian woman of the middle classes is a killer of capacity in man. In a similar line Captain Shotover puts the blame on Ariadne for not having reached the seventh degree of concentration. (Shaw, 1919: 52-53)

Because the Capua dwellers, as Shaw calls them in Heartbreak House, the cultured and leisured classes of England would not take responsibility, but lose themselves in their self pity, the horse-breakers, Junkers or the Militarists of England

\footnotetext{
${ }^{7}$ Lord Byron's Don Juan starts with an invocation to search for "a hero".
} 
would use all power and make decisions on all grave matters, on matters of life and death. Ariadne Utterword's speech gives us the best opportunity to see the horsebreakers' point of view:

LADY UTTERWORD: I assure you, all this house needs to make it a sensible, healthy, pleasant house, with good appetites and sound sleep in it, is horses.

MRS HUSHABYE: Horses! What rubbish!

LADY UTTERWORD: Yes: horses. Why have we never been able to let this house? Because there are no proper stables. Go anywhere in England where there are natural, wholesome, contented, and really nice English people; and what do you always find? That the stables are the real centre of the household; and that if any visitor wants to play the piano the whole room has to be upset before it can be opened, there are so many things piled on it. I never lived until I learned to ride... There are only two classes in England: the equestrian classes and the neurotic classes. It isn't mere convention: everybody can see that the people who hunt are the right people and the people who don't are the wrong ones. (Shaw, 1919: 141)

According to Lady Utterword, Ariadne Captain Shotover's other daughter, unless a man loves hunt and shoot no matter how well-educated he is or what artistic or intellectual qualifications he holds, he cannot be considered a happy and self-satisfied man. Ariadne argues that people should stop artistic and intellectual pretensions but follow their hunting instincts.

In the preface to the play, Shaw makes a distinction between horsebreakers and heartbreakers, the ones who belonged to the horseback hall and heartbreak house, or he likes to call them dwellers of Capua and barbarians. The educated and cultured class gave themselves to heartless pleasure in a world where conscience was expelled and sent to exile. Shaw makes this point quite openly in his review of Oscar Wilde's Importance of Being Earnest criticizing the play most severely calling it heartless, while admiring his previous plays. (Shaw, 1895) Shaw condemns the heartbreakers for fully abandoning the worldly political arena to the barbarian. The vacuum is filled with the horsebreakers or barbarians like Mangan or the burglar Billie Dunn. The irresponsibility of the heartbreakers "delivered the world over to the control of ignorant and soulless cunning and energy, with the frightful consequences" which overtook it. (Shaw, 1919: 17). So Shaw conceives the cultural battle between the cultured, book reading, art creating heartbreakers (The Trojans) and the "barbarian" horsebreakers (Achaeans) as vitally significant.

Both of these classes waste their time, energy and intellect so irresponsibly that the only outcome of such drifting which will wake them up from their sleep is the most 
cruel and destructive bombings of the night. At the end Shaw emphasizes the inevitability of war in such a society. The destructiveness and pain of the war can be the only eye opener, only teacher which might show the society what the cost of their irresponsible behavior would be.

\section{The Hero Facing Reality}

One of the central focuses of Heartbreak House is how characters in the play who represent the middle classes would not be told the truths and how they would be offended by them. They live in a world of deceptions. They have a very weak connection with truth as it is. They would justify themselves in a world they constructed out of lies. They have such a weak connection with the world out of themselves and their personal affairs that although they talk about everything from food to sex, to arts to business, servants, love, Shakespeare, hypnotism, money, inventions and all none refers to the war even once. Yet we can see what that civilization value in the dialogue between Captain Shotover and his daughter Hesione Hushabye:

CAPTAIN SHOTOVER: Where is all the money you had for that patent lifeboat I invented?

MRS HUSHABYE: Five hundred pounds; and I have made it last since Easter...

CAPTAIN SHOTOVER: Only 500 pounds for that lifeboat! I got twelve thousand for the invention before that.

MRS HUSHABYE: Yes, dear; but that was for the ship with the magnetic keel that sucked up submarines. Living at the rate we do, you cannot afford life-saving inventions. Can't you think of something that will murder half Europe at one bang? (Shaw, 1919: 88)

Mrs Hushabye's speech is central in my understanding of the play as Shaw here condemns the capitalist mentality which ignores the sufferings or murder of others as long as the self is satisfied. As also Kruse observes Heartbreak House is essentially "an expression of a well established and continued commitment to a socialist understanding of history and civilization, including even the horror of the first world war." (Kruse, 1987: 103) Kruse also notes that "Heartbreak House is an attempt to respond to his sense of crisis in civilization with social and cultural analysis which might explain the pathological conditions of the old order (Kruse 100)." When the bombs explode and kill the horsebreakers they welcome the reality with open arms and embrace it despite its destructiveness. It is Hector Hushabye who voices this sentiment in the play: 
Heaven's threatening growl of disgust at us useless futile creatures. [Fiercely]. I tell you, one of two things must happen. Either out of that darkness some new creation will come to supplant us as we have supplanted the animals, or the heavens will fall in thunder and destroy us. (Shaw, 1919: 140)

Hector's speech echoes another speech in one of Shaw's most prominent plays Man and Superman (1903). In that famous speech The Devil condemns man thus:

THE DEVIL: And is Man any the less destroying himself for all this boasted brain of his? ...I have examined man's wonderful inventions...in the arts of life man invents nothing; but in the arts of death he outdoes nature herself, and produces by chemistry and machinery all the slaughter of plague, pestilence and famine. The peasant I tempt today eats and drinks what was eaten and drunk by the peasants of ten thousand years ago...But when he goes out to slay, he carries a mechanism of marvel...the power that governs the earth is not the power of life but of Death... (Shaw, 1903: 142-144)

Despite this rather pessimistic speech by the Devil in the dream section, the third act of the play also known as "Don Juan in Hell", Man and Superman still ends with hope and the declaration of the union between Jack and Ann which means regeneration. It also carries the potential of creating the superman. In spite of his hesitations and objections Jack yields to Life Force and accepts to take part in the regeneration. Whereas, Heartbreak House ends with a destructive scene, the only hope is to destroy in order to be able to reconstruct.

The cruel and destructive, murderous war was welcomed by the heartbreak house since they knew not what to do with peace all consumed in self-pity, the war gave them an opportunity to forget their hypochondriacally posed petty problems, the artificial and unnatural issues, so they welcomed death and they had to "make a merit of dying" since they did not know how to live in harmony and peace. Shaw depicts the state of England before the war thus:

Heartbreak House was far too lazy and shallow to extricate itself from this palace of evil enchantment. It rhapsodized about love; but it believed in cruelty. It was afraid of the cruel people; and it saw that cruelty was at least effective. Cruelty did things that made money, whereas Love did nothing but prove the soundness of Larochefoucauld's saying that very few people would fall in love if they had never read about it. Heartbreak House, in short, did not know how to live, at which point all that was left to it was the boast that at least it knew how to die: a melancholy accomplishment which the outbreak of war presently gave it practically unlimited opportunities of displaying. Thus were the firstborn of 
Heartbreak House smitten; and the young, the innocent, the hopeful, expiated the folly and worthlessness of their elders. (Shaw, 1919: 15-16)

The irresponsible attitude of the middle and upper classes would not do their duty but shrink from taking any responsibility in the fate of humanity. Their selfcentredness and self-destructive selfishness are depicted quite severely. Although they have the means to change the world they live in and prevent destruction to occur they are so involved and absorbed by their own affairs and self-pity that they fail to see the catastrophe brewing just in front of them. The Zeppelin attack and the bombs make them realize what was happening but still incredibly they find the destruction quite exciting and assume a welcoming attitude towards war and the explosions: "MRS HUSHABYE: But what a glorious experience! I hope they'll come tomorrow night again." (Shaw, 1919: 160)

Everyone has a pose, a mask as it is almost a sin, something to be ashamed to appear as one sincerely should in an honest state of things. Part of the charm of the piece stems from that surprising and rather enigmatic aspect of the play. Visitors to the heartbreak house are shocked at first when they first come to that "unnatural house" Mangan says that even burglars cannot act naturally in this house but they would come up with some sort of unusual and queer demands. For instance, the Burglar would not go away without being paid for his conversion. For he heavily relies on the moral weakness, and irresponsible attitude of the upper and middle classes. None of these people would take any measures to punish a burglar as they would not spare one day of their leisure to go to court and stand witness: "Am I to be robbed of my salvation to save you the trouble of spending a day at the sessions? Is that justice? Is it right? Is it fair to me?" (Shaw, 1919: 118) The responsibility and duty itself is too much for their lifestyle which excludes any kind of effort or sacrifice. Yet again Shaw still sides with heartbreakers against the horseback hall.

\section{Conclusion}

Barbarism versus Capua, philistines without any principles or morality against cultured without any moral responsibility, or scope which might give them social responsibility to help the others for the good of the whole thus themselves; selfish little clods who are drowned in their self-pity. Yet, for Grene despite his heartbreaking disappointment for their helplessness and listlessness, "When it came to the horrors of war and war fever," Shaw's sympathies still go with the "liberal intellectuals of heartbreak House against the Philistines represented by Mangan, Randall or Sir Hastings Utterword" (Shaw, 1919: 126). As Mangan boasts in the play, Capua, or the heartbreakers have no power at all but governed by the horseback dwellers, the barbarians who know no morals, or principles but practically making more and more 
money. In the play, Hector refers to the fact talking to Captain Shotover and the captain says that the heartbreakers ought to destroy the horsebreakers otherwise they will be annihilated by them: When Hector asks rather conscientiously what right they had to judge the barbarians Shotover reminds him that while he is hesitating and losing time the Horseback hall constantly criticize and condemn them and told that to their face: "What are they that they should judge us? Yet they do, unhesitatingly. There is enmity between our seed and their seed. They know it and act on it, strangling our souls. They believe in themselves. When we believe in ourselves, we shall kill them." (Shaw, 1919: 86) I would like to refer to long a passage from the Preface to Heartbreak House:

\begin{abstract}
Just as Ibsen's intensely Norwegian plays exactly fitted every middle and professional class suburb in Europe, these intensely Russian plays fitted all the country houses in Europe in which the pleasures of music, art, literature, and the theatre had supplanted hunting, shooting, fishing, flirting, eating, and drinking. The same nice people, the same utter futility. The nice people could read; some of them could write; and they were the sole repositories of culture who had social opportunities of contact with our politicians, administrators, and newspaper proprietors, or any chance of sharing or influencing their activities. But they shrank from that contact. They hated politics. They did not wish to realize Utopia for the common people: they wished to realize their favorite fictions and poems in their own lives; and, when they could, they lived without scruple on incomes which they did nothing to earn. (Shaw, 1919: 8)
\end{abstract}

The point Shaw makes here is directly related to what Vico calls "respublica ['the public concern'] and Hegel calls "serving the universal". Hector is the epitome of not being able to fulfill this potential. He has the intellectual, artistic, social, physical capabilities to lead his society to a better future. He also sees what is wrong and what it takes to make a better, more livable world but as Shaw maintains he shrinks from that. In "the Revolutionist's Handbook and Pocket Companion by John Tanner M.I.R.C., Member of the Idle Rich Class", the epilogue to Man and Superman (1903), Shaw describes the "world betterers" that could improve the world:

Until there is an England in which every man is a Napoleon, a Rome in which every man is a Caesar, a Germany in which every man is a Luther plus a Goethe, the World will be no more improved by its heroes than a Brixton villa is improved by the pyramid of Cheops. The production of such nations is the only real change possible to us. (Shaw, 1903: 224-225)

When it comes to Heartbreak House, considering the fact that the play is Shaw's initial response to a war that claimed the lives of millions of people from all around the world and it is the war which would pave the way the to an even more destructive one in another twenty years, Shaw's concern for men is even more urgent and serious. 


\section{WORKS CITED}

AUERBACH, Eric. "Vico and Aesthetic Historism." Scenes from the Drama of European Literature. University of Minnesota Press, Minneapolis, 1949. 110-18.

CARLYLE, Thomas. (1901). Sartor resartus; and, On heroes, hero-worship and the heroic in history. Macmillan, 1836.

COLEMAN, D. C. "Fun and games: two pictures of Heartbreak House.” Drama Survey, issue 5, 1966-67. 223-236.

ERVINE, St. John. "Shaw's View of Heartbreak House”. Shaw: Interviews and Recollections. Ed. A.M. Gibbs. Basingstoke and London: Macmillan, 1990. 296.

FAGLES, Robert. Trans. Homer. The Iliad. New York: Penguin Books, 1990.

FRANK, Joseph. "Exile and the kingdom: the incipient absurdity of Milton and Shaw." Mosaic, 9, issue i, 1975. 111-121.

FRANK, Joseph. 'Internal vs. external combustion: Dickens' Bleak House and Shaw's Major Barbara and Heartbreak House." Shaw Review, issue 20, 1977. 126-134.

FREEBORN, Richard. "A Shavian fantasia in the Russian manner and Chekhov's last play.” Shavian, 8, issue vii, 1999-2000. 6-9.

GARNER, Stanton B. "The absent voice: narrative comprehension in the theater." Urbana: Univ. of Illinois Press, 1989. 125-147.

GARNER, Stanton B. “Shaw's comedy of disillusionment: Major Barbara and Heartbreak House". Modern Drama, issue 28, 1985. 638-658.

GIBBS, A.M. The Art and Mind of Shaw: Essays in Criticism. London and Basingstoke: The Macmillan Press, 1983.

GRENE, Nicholas. Bernard Shaw: A Critical View. London: The Macmillan Press, 1984.

GRIFFITH, Gareth. Socialism and Superior Brains: The Political Thought of Bernard Shaw. London and New York: Routledge, 1993. 
HANDLEY, Miriam. "Chekhov translated: Shaw's use of sound effects in Heartbreak House." Modern Drama, issue 42, 1999. 565-78.

HEGEL, G.W.F. (1807). The Phenomenology of the Spirit. Trans. A.V. Miller. Oxford: Oxford UP, 1977.

HENDERSON, Archibald. "Shaw on Writing Plays". Shaw: Interviews and Recollections. Ed. A.M. Gibbs. Basingstoke and London: Macmillan, 1990. 313-316.

"hero". https://www.merriam-webster.com/dictionary/hero. March 15, 2017.

HOLROYD, Michael. Bernard Shaw: Volume II, 1898-1918, The Pursuit of Power. London: Chatto and Windus, 1989.

HOLROYD, Michael. Bernard Shaw: Volume III, 1918-1950, The Lure of Fantasy. London: Chatto and Windus, 1991.

HOMER. The Iliad. Trans. Robert Fagles. New York: Penguin Books, 1990.

HORNBY, Richard. "The symbolic action of Heartbreak House." Drama Survey, issue 7, 1968-1969. 5-24.

HOY, Cyrus. "Shaw's tragicomic irony: from Man and Superman to Heartbreak House." Virginia Quarterly Review, issue 47, 1971. 56-78.

KRUSE, Alex. "Bernard Shaw's Heartbreak House: The War in 'Neverland"'. Sydney Studies in English Journal, issue 13, 1987. 100-119.

LI, Kay. "Heartbreak House and the Trojan War." Shaw and Other Matters: A Festschrift for Stanley Weintraub on the Occassion of His Forty-Second Anniversary at The Pennsylvania State University. Ed. Susan Rusinko. Selingsrove PA and London: Susquehanna University Press and Associated University Press, 1998. 83-92.

SHAW, George Bernard. (1898). "Candida." The Plays of Shaw. Douglas Editions, 2009. 3052-4338.

SHAW, George Bernard. (1919). Heartbreak House. London and New York: Penguin, 1964.

SHAW, George Bernard. (1903). Man and Superman: A Comedy and a Philosophy. London and New York: Penguin, 1964. 
SHAW, George Bernard. (1895). “On The Importance of Being Earnest 1895”. https://earnestdramaturgy.files.wordpress.com/2013/06/shaw-review-1895.pdf. March $15,2017$.

SHAW, George Bernard. (1901). "Notes to Caesar and Cleopatra". The Plays of Shaw. Douglas Editions, 2009. 6415-6569.

SHAW, George Bernard. (1902). "The Author's Apology" to Mrs Warren's Profession (1902). The Plays of Shaw. Douglas Editions, 2009. 31335-31755.

SHAW, George Bernard. (1913). "Pygmalion." The Plays of Shaw. Douglas Editions, 2009. 24768-26654.

VICO, Giambattista. (1725). The First New Science. Ed. and Trans. Leon Pompa. Cambridge and New York: Cambridge UP, 2002.

WEINTRAUB, Stanley. "Shaw's Troy: Heartbreak House and Euripides' Trojan Women." SHAW The Annual of Bernard Shaw Studies, Volume 29, 2009. 41-49.

YOUNG, Stark. "Heartbreak Houses: 1948”. Bernard Shaw: A Critical Study. Ed. Louis Kronenberger. Cleveland and New York: The World Publishing Company, 1953. 